\title{
The ALA-D Activity Test in Lead-Exposed Grey Mullet Mugil auratus
}

\author{
M. Krajnović-Ozretić and B. Ozretić
}

Center for Marine Research, 'Rudjer Bošković’ Institute, 52210 Rovinj, Yugoslavia

\begin{abstract}
The effect of sublethal exposure of grey mullet Mugil auratus Risso to lead ( $82 \mathrm{~d}$ in $500 \mu \mathrm{g} P \mathrm{~b} \mathrm{1}^{-1}$ ) was recorded by means of ALA-D activity and hemoglobin concentration decrease. Maximum ALA-D inhibition (about $40 \%$ ) occurred after the second week, but the lead accumulation in the blood still increased. The specific pH optimum (pH 6.0-6.2), the optimal substrate concentration ( $4 \mathrm{mM} \mathrm{ALA})$ and the routine temperature incubation $\left(37^{\circ} \mathrm{C}\right)$ in the testing procedure were determined. Cadmium, copper and mercury $\left(10^{-7}\right.$ to $\left.10^{-3} \mathrm{M}\right)$ added 'in vitro' produce significant inhibition of ALA-D, while lower concentrations of zinc $\left(10^{-7}\right.$ to $\left.10^{-5} \mathrm{M}\right)$ slightly increase enzyme activity of unexposed mullets. Higher concentrations of zinc $\left(10^{-5}\right.$ to $\left.10^{-4} \mathrm{M}\right)$ strongly reactivate the inhibited ALA-D of the mullets previously exposed to lead.
\end{abstract}

\section{INTRODUCTION}

Lead toxicity has largely been studied with a view of its detection in, and clinical treatment of, people professionally or accidentally exposed to this metal. In the marine environment it was accepted, for a long period, that the presence of inorganic lead could not be considered harmful. The solubility of lead in seawater is very low $(<1 \mathrm{ppm})$ - a concentration that does not produce detectable lethal effects. According to many authors, there appears to be no evidence thus far that lead could be considered a direct hazard to marine fishes.

However, the criteria used in lethal concentration tests are limited to a drastic definition of the endpoint measured: death or survival. They do not evaluate metabolic disfunctions and physiological disorders in the test organisms. In these cases, as Hodson et al. (1977) emphasized, one population could be injured, reduced in size, or even disappear without evidence of direct mortality. To evaluate sublethal damage satisfactorily, long-term sophisticated experiments have to be conducted which, for technical and practical reasons, are very difficult or even impossible to perform.

According to several recent reports (Jackim, 1973; D'Amelio et al., 1974; Hodson, 1976; Hodson et al., 1977; Johansson-Sjöbeck and Larsson, 1979) the ery- throcyte ALA-D activity test is a satisfactory short-term indicator of long-term toxicity of lead to fishes.

Delta aminolevulinic acid-dehydratase (ALA-D, E.C. 4.2.1.24) is a key enzyme in the production of hemoglobin and other components with appropriate porphyrin skeleton, including cytochrome and peroxidase. This enzyme is present in appreciable amounts in erythrocytes and it has also been detected in a large variety of other animal and plant tissues. It is generally known that erythrocyte ALA-D activity is strongly and specifically depressed in both human and animal lead poisoning, and that the degree of inhibition is related to the presence of lead in blood. In fact, erythrocyte ALA-D activity is very sensitive to lead, and partial inhibition occurs long before any other biological effects are measurable. ALA-D is rich in sulphydryl groups and thiols are required for maximal enzyme activity and, because of the high affinity between $\mathrm{SH}$ groups and metal ions, especially heavy metals, it can be expected that metals may be bound to the enzyme in its natural environment. There are numerous, but sometimes contradictory, reports about the metal requirement of this enzyme. Several authors report copper as a cofactor of ALA-D (Iodice et al., 1958; Komai and Neilands, 1968; Evans, 1973), while others indicate that zinc is involved in its activity (Abdulla and Haeger-Aronsen, 1971; Wilson et al., 1972; Cheh and Neilands, 1973; Finelli et al., 1974). 
The results discussed in this paper represent an initial attempt to evaluate the inhibitory effect of lead on the erthrocyte ALA-D of the grey mullet Mugil auratus exposed to sublethal concentrations of lead in seawater. The effect of other metal ions have also been tested in 'in vitro' experiments.

\section{MATERIAL AND METHODS}

In each experiment, 6 grey mullet Mugil auratus Risso, average weight: $197 \pm 39 \mathrm{~g}$, were exposed to a nominal lead concentration of $500 \mu \mathrm{g} \mathrm{Pb} \mathrm{l}^{-1}$ seawater in a 200-l tank. Lead, as $\mathrm{Pb}\left(\mathrm{NO}_{3}\right)_{2}$, was continuously added to seawater by a toxicant doser. The flow rate through the tank was $21 \mathrm{~min}^{-1}$ or about 7 tank exchanges $\mathrm{d}^{-1}$. Temperature was maintained constant at $17^{\circ} \mathrm{C}$ by means of a heat-exchange unit. Fish were fed daily to satiation and the tank was cleaned shortly after. The real concentration of lead in the system was measured frequently at the incoming and outflowing point of the tank. The anodic stripping voltametry method (ASV) of analysis was used. The mean concentration of lead at the incoming point was $487 \pm 12 \mu \mathrm{g} \mathrm{l}^{-1}$; at the outflow the concentration was decreased to an average of $452 \pm 52 \mu \mathrm{g} \mathrm{l}^{-1}$. It should be expected that adsorption and precipitation processes in the tank depress the original concentration of lead in the solution. Blood samples of about 0.3 to 0.5 ml were obtained by heart punction.

The ALA-D activity in whole blood samples was measured by the modified method described by Tomokuni (1974). Samples of $0.1 \mathrm{ml}$ of blood were hemolyzed with $0.5 \mathrm{ml}$ of $0.01 \mathrm{M} \mathrm{Na}$-phosphate buffer at $\mathrm{pH}$ 6.0. Afterwards, $0.2 \mathrm{ml}$ of $0.2 \mathrm{M} \mathrm{Na}$-phosphate buffer and $0.2 \mathrm{ml}$ of $0.02 \mathrm{M}$ ALA was added and the obtained mixture incubated for $1 \mathrm{~h}$ at $37^{\circ} \mathrm{C}$. The reaction was then stopped with $1 \mathrm{ml}$ TCA $10 \%$ TCA containing $0.1 \mathrm{M} \mathrm{HgCl}_{2}$ ) and centrifuged. One ml of supernatant was mixed with $3 \mathrm{ml}$ of Ehrlich reagent and the extinction $\left(E_{555}\right)$ was measured 10 min after. The enzyme activity was expressed as the change in optical density in relation to hemoglobin concentration and time $\left(\mathrm{E}_{555} \mathrm{~g}^{-1} \mathrm{Hb} \mathrm{h}^{-1}\right)$.

Hemoglabin concentration (g $100 \mathrm{ml}^{-1}$ ) was determined by the standard method, after conversion to cyanmethemoglobin (Wintrobe, 1974). The lead concentration in whole blood was measured by the ASV method after the wet digestion of $0.05 \mathrm{ml}$ blood aliquots.

The effect of other metal ions $\left(\mathrm{Zn}^{2+}, \mathrm{Al}^{3+}, \mathrm{Cd}^{2+}\right.$, $\mathrm{Hg}^{2+}$ and $\mathrm{Cu}^{2+}$ ) on the erythrocyte ALA-D activity was studied 'in vitro' by adding appropriate quantities of the metals to hemolysed blood samples obtained from control or lead exposed fish. The preincubation time, before the addition of ALA, was $30 \mathrm{~min}$.

\section{RESULTS AND DISCUSSION}

ALA-D activity, hemoglobin concentration and lead concentration in whole blood samples were measured during a period of $82 \mathrm{~d}$ (Fig. 1). The initial activity of ALA-D was about 200 extinction units ( \pm 38 ). A very marked repressive effect of lead on ALA-D activity was observed even as early as the first week. The maximal inhibition was reached during the second week, and remained at that level until the end of the experiment. The normal hemoglobin concentration of about $8.8 \mathrm{~g}$ $100 \mathrm{ml}^{-1}( \pm 1.4)$ decreased to $5.5 \mathrm{~g}^{100 \mathrm{ml}^{-1}}( \pm 1.2)$.

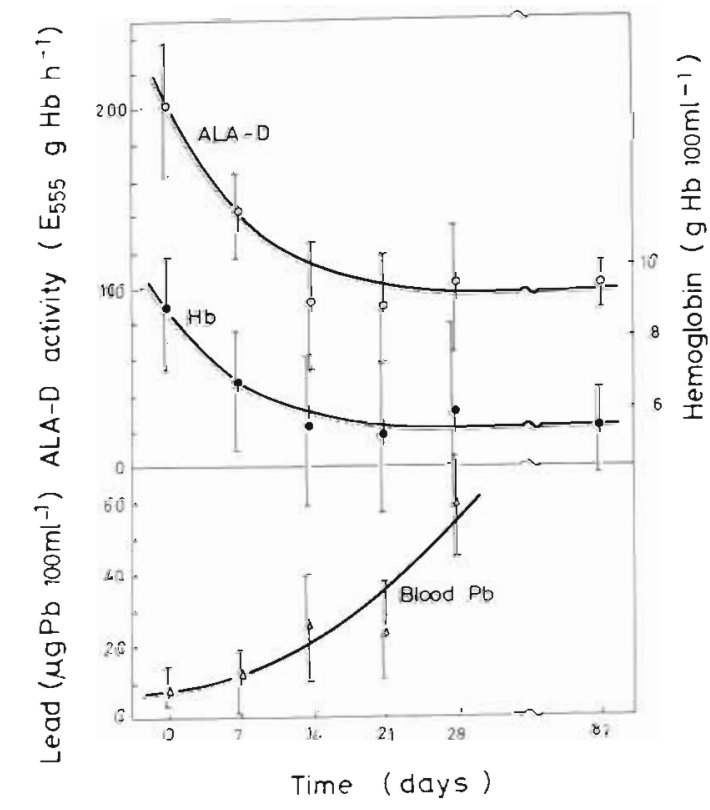

Fig. 1. Mugil auratus. ALA-D activity, hemoglobin concentration and lead concentration in blood samples of individuals exposed to lead

The hemoglobin values are strongly correlated in time $(r=+0.967)$ with the ALA-D activity decrease. This figure is in very good agreement with the results described by Johansson-Sjöbeck and Larsson (1979) obtained after a $30 \mathrm{~d}$ exposure of rainbow trout to $300 \mu \mathrm{g} \mathrm{Pb} \mathrm{l^{-1 }}$. Similarly, lead concentration in the blood, compared to the ALA-D activity, showed the expected negative correlation $(r=-0.563)$, but was not statistically significant. In fact, after the second week, when the enzyme activity was established at the lower level, the accumulation of lead in blood was still increasing. 


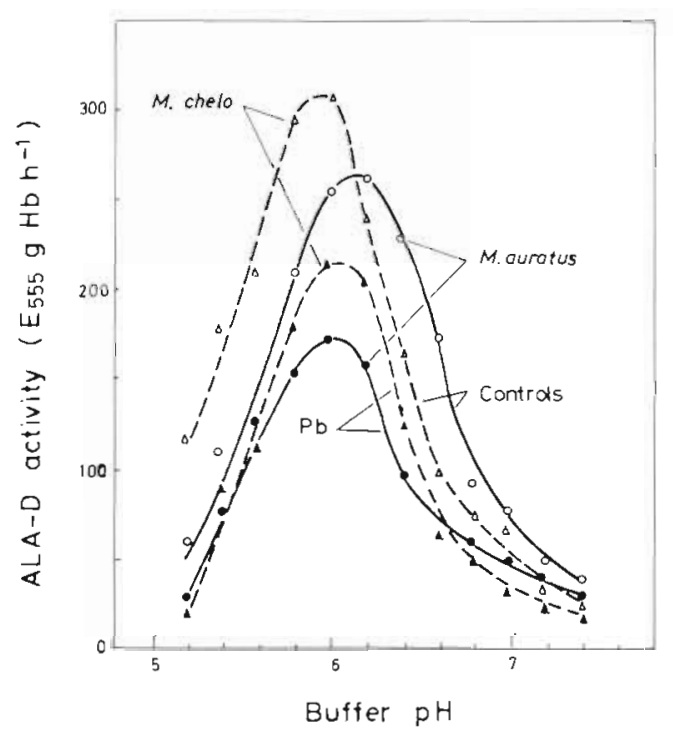

Fig. 2. Mugil auratus and Mugil chelo. Variation of ALA-D activity in controls and lead-exposed mullets as a function of $\mathrm{pH}$

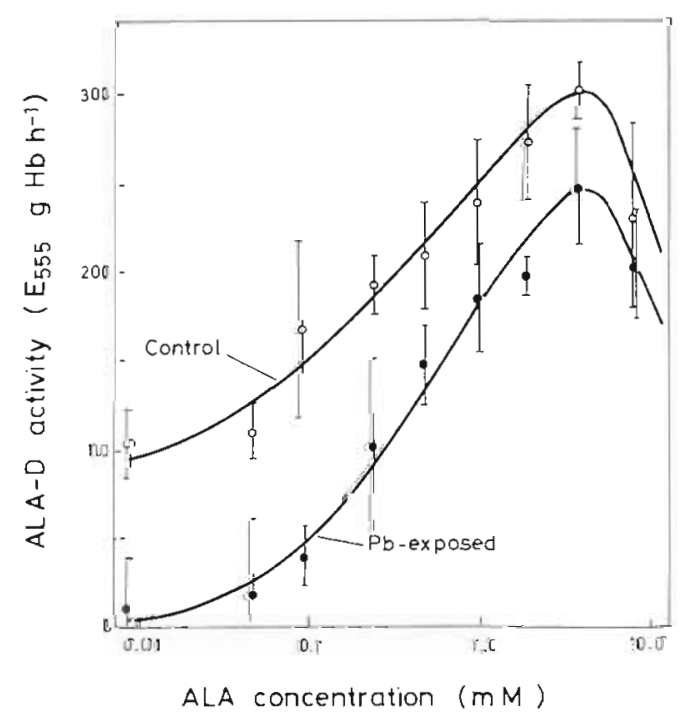

Fig. 3. Mugil auratus. Effect of ALA concentration on ALA-D activity in controls and lead exposed individuals at $\mathrm{pH} 6.0$

When measuring the enzyme activity, in general, the $\mathrm{pH}$ control of the reacting mixture is rather crucial. According to Tomokuni (1974) two ALA-D pH optima were found in human blood: at $\mathrm{pH} 6.8$ for the control group and at $\mathrm{pH} 6.0$ for professionally lead exposed people.

In our experiments, the ALA-D activity measured in relation to various $\mathrm{pH}$ levels showed a broad peak between $\mathrm{pH} 5.8$ to 6.4 , with the maximum activity at pH 6.0 to 6.2 (Fig. 2). Practically identical results were obtained with another grey mullet species, Mugil chelo, and according to the values obtained on the

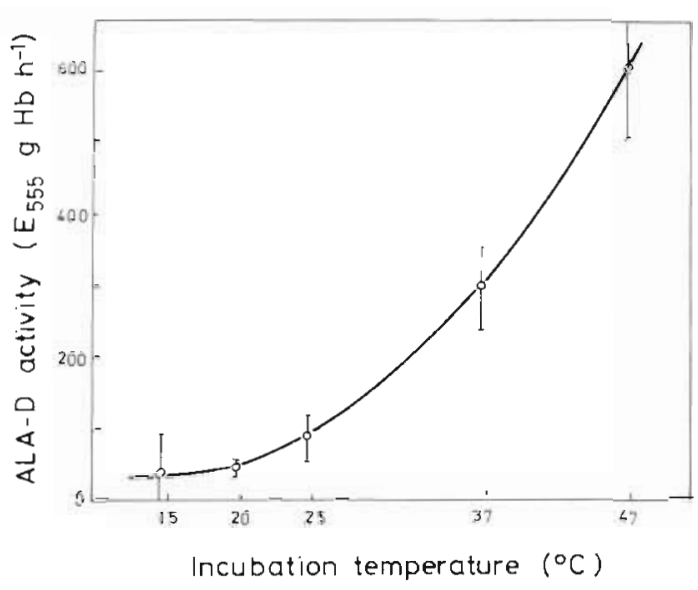

Fig. 4. Mugil auratus. Influence of incubation temperature on ALA-D activity of controls

rainbow trout (Hodson, 1977) it can be generally expected that the optimum ALA-D pH in fishes lies in the interval of $\mathrm{pH} 6.0$ to 6.4 , with no secondary peaks and no difference regarding the $\mathrm{pH}$ optima of lead exposed or control individuals.

The optimum substrate concentration and incubation temperature were also tested. The ALA concentration of $4 \mathrm{mM}$ gives the highest ALA-D activity both in control as well as in lead exposed fish (Fig. 3). The effect of incubation temperature was tested at 15,20 , 25, 37 and $47^{\circ} \mathrm{C}$ (Fig. 4). Between $25^{\circ} \mathrm{C}$ and $47^{\circ} \mathrm{C}$ the ALA-D activity was linearly correlated with temperature. In routine testing the usual temperature of $37^{\circ} \mathrm{C}$ was used.

The results of Hodson (1977) suggest that in 'in vivo' experiments the ALA-D activity in fish is specifically inhibited only by lead. In fact the ALA-D activity of rainbow trout surviving lethal concentration of cadmium, copper and zinc does not exibit any significant activity change. There was observed some activity depression in mercury treated fish (about $6 \%$ only), while zinc in exposed trout during the first period caused a slight increase in ALA-D activity followed by a definitive depression of the same magnitude.

In our experiments, the ALA-D activity response in normal blood hemolysate, loaded 'in vitro' with several concentrations of cadmium, copper, mercury, aluminium, zinc and lead itself were measured (Fig. 5).

Lower concentrations of zinc $\left(10^{-7}, 10^{-5} \mathrm{M}\right)$ slightly increase the activity of the enzyme (about $10 \%$ ) while the same concentrations of aluminium have no effect. Higher concentrations of both metals produce significant inhibition. In contrast, even the lowest concentrations of cadmium, copper and mercury decreased the ALA-D activity. At the lower concentrations $\left(10^{-7}\right.$, $10^{-6} \mathrm{M}$ ) mercury and copper decreased the enzyme activity to about $90 \%$, cadmium and lead at about 


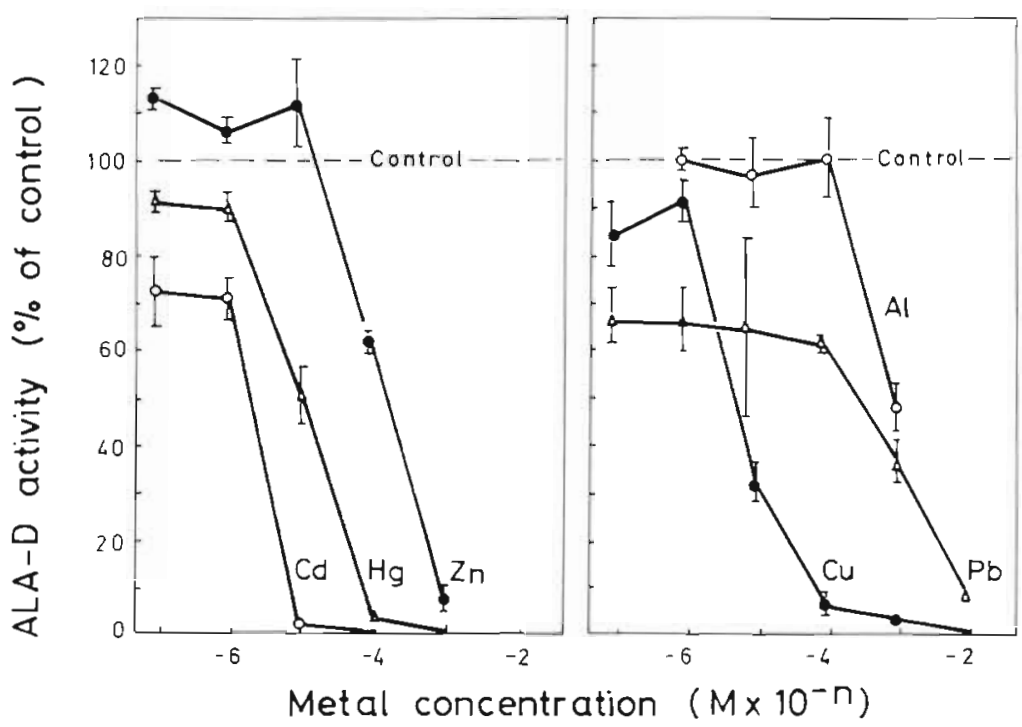

Fig. 5. Mugil auratus. ALA-D activity in relation to various metal concentrations added 'in vitro'

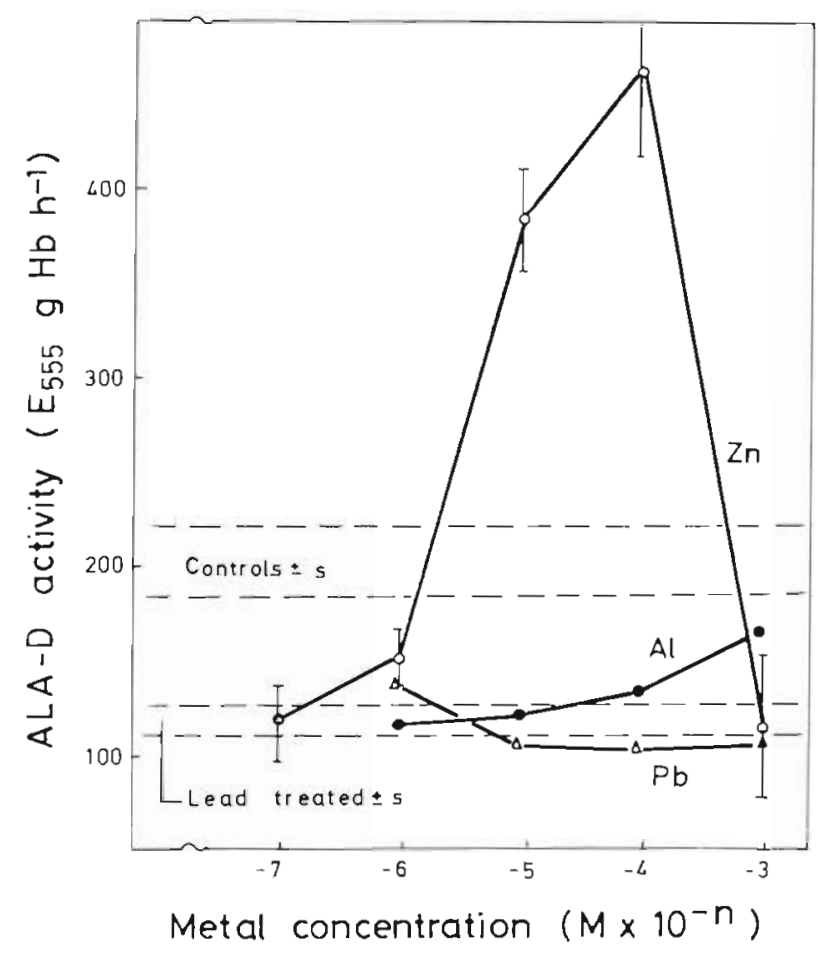

Fig. 6. Mugil auratus. Restoring effect of zinc ( $\pm S$ ) and aluminium ions added 'in vitro' to blood samples of leadexposed individuals. The depressing effect of additional lead is not significant

$70 \%$. But by increasing their concentrations $\left(10^{-5}\right.$ to $\left.10^{-2} \mathrm{M}\right)$ the inhibitory effect of these metals was drastically enhanced and it was higher than the effect of lead. This can be explained because of the higher affinity of cadmium, copper and mercury compared to lead in relation to the sulphydryl groups of the enzymatic system (or systems) involved (Finelli, 1977).

Identical measurements were made in blood samples from mullets treated 'in vivo' with lead (Fig. 6). These results indicate that the inhibitory effect of lead on ALA-D is a reversible process and that a relevant reactivation occurs after the addition of zinc. It is pertinent to point out that the concentration of $10^{-4} \mathrm{M} \mathrm{Zn}$ in the blood of control individuals produces a significant inhibition of ALA-D activity to the level of, about, $60 \%$ (Fig. 5), while in lead exposed mullets the concentration of $10^{-5}$ to $10^{-4} \mathrm{M} \mathrm{Zn}$ reactivates the ALA-D activity to a higher level than in the control group (Fig. 6). Very similar results were described by Finelli (1977) in a case of plumbism therapy suggesting that the restoring effect of zinc in lead-exposed individuals is presumably related to the competitive binding of lead or zinc ions to ALA-D: one acting as inhibitor, the other as activator. From these results it can be expected that for the reactivation of the already lead-inhibited ALA-D, a relatively higher concentration of zinc is required, indicating that this enzyme has greater affinity for lead than for zinc

The maximum restoring effect of aluminium was obtained at the concentration of $10^{-3} \mathrm{M}$, but it is significantly lower than the zinc effect, and it does not reach the values of the control group.

The exposition of samples of the already exposed fish to additional lead does not cause any significantly higher inhibitory effect. In view of the lowest ALA-D activity obtained after the second week of exposition of mullet to lead (Fig. 1), it may be assumed that the 
maximum inhibitory effect was definitely reached and no additional inhibition can be produced. This figure suggests that in the ALA-D activity test, the eventual manipulative lead contamination does not influence the results. In contrast, the determination of lead concentrations in small blood samples is methodologically very complex and very sensitive to manipulative contamination.

The restoring capacity of ALA-D by zinc at concentrations of $10^{-5}$ and $10^{-4} \mathrm{M}$ was particularly high in lead treated fish. This property could be applied to test whether a fish was previously exposed to lead.

From these results the following conclusions are drawn:

- The ALA-D activity test is satisfactory for assessing lead contamination in fishes; it is more sensitive and easier to perform than direct determinations of lead concentrations in tissues.

- The inhibitory effect of lead to ALA-D is not proportional to exposure time nor to lead concentration in the blood.

- The accumulation of lead in mullet produces anemia, probably as a result of injury to the hematopoetic system.

- Zinc is very effective in restoring the ALA-D activity of the exposed mullets to lead.

- Cadmium, copper and mercury added 'in vitro' produce a significant depression of ALA-D activity.

Acknowledgements. This work has been performed within the frame of the FAO/UNEP Joint Coordinated Project on Pollution in the Mediterranean Sea with financial support of the Self-management Community of Interest for Scientific Research of S. R. Croatia. The authors are grateful to Dr. M. Branica and collaborators for lead analysis and to S. Dragic and G. Sošić for technical assistance. Helpful advice and critical review given by Miss W. de Ligny and by Professor M. Gilmartin are gratefully acknowledged.

\section{LITERATURE CITED}

Abdulla, M., Haeger-Aronsen, B. (1971). ALA-dehydratase activation by zinc. Enzyme 12: 708-710

Cheh, A., Neilands, J. B. (1973). Zinc, an essential metal ion for beef liver delta-aminolevulinate dehydratase. Biochem. biophys. Kes. Commun. 55: 1060-1063

D'Amelio, V., Russo, G., Ferraro, D. (1974). The effect of heavy metal on protein synthesis in crustacean and fish. Revue int. Océanogr. méd. 33: 111-117

Evans, G. W. (1973). Copper homeostasis in the mammalian system. Physiol. Rev. 53: 535-570

Finelli, V. N. (1977). Lead, zinc and 5-aminolevulinate dehydratase. In: Lee, S. D. (ed.) Biochemical effects of environmental pollutants. Ann Arbor Science, Ann Arbor, Mich., pp. 351-363

Finelli, V. N., Murphy, L., Peirano, W. B., Petering, H. G. (1974). 5-aminolevulinate dehydratase, a zinc dependent enzyme. Biochem. biophys. Res. Commun. 60: 1418

Hodson, P. V. (1976). Delta-amino levulinic acid dehydratase activity of fish blood as indicator of a harmful exposure to lead. J. Fish. Res. Bd Can. 33: 268-271

Hodson, P. V., Blunt, B. R., Spry, D. J., Ansten, K. (1977). Evaluation of erythrocyte delta-amino levulinic acid dehydratase activity as a short-term indicator in fish of a harmful exposure to lead. J. Fish. Res. Bd Can. 34: $501-508$

Iodice, A. A., Richter, D. A., Schulman, M. P. (1958). Copper content of purified 5-aminolevulinic acid dehydratase. Fedn Proc. Fedn Am. Socs exp. Biol. 17: 248

Jackim, E. (1973). Influence of lead and other metals on fish delta-aminolevulinate dehydratase activity. J. Fish. Res. Bd Can. 30: 560-563

Johansson-Sjöbeck, M.-L., Larsson, $\AA$. (1979). Effects of inorganic lead on delta-aminolevulinic acid dehydratase activity and hematological variables in the rainbow trout, Salmo gairdnerii. Arch. Environm. Contam. Toxicol. 8: 419-431

Komai, H., Neilands, J. B. (1968). Effect of zinc ions on 5aminolevulinate dehydratase in Ustilago sphaerogena. Archs Biochem. Biophys. 124: 456-461

Tomokuni, K. (1974). 5-aminolevulinic acid dehydratase test for lead exposure. Arch. environ. Health 29: 274-281

Wilson, E. L., Burger, P. E., Dowdle, E. B. (1972). Beef-liver 5aminolevulinic acid dehydratase. Purification and properties. Eur. J. Biochem. 29: 563--571

Wintrobe, M. M. (1974). Clinical hematology, 7th ed., Lea and Febiger, Philadelphia 